\title{
PEMAHAMAN PERIODISASI SEJARAH GEREJA UMUM DI SEKOLAH TINGGI AGAMA KRISTEN NEGERI KUPANG
}

\author{
Leryani Mince Maria Manuain \\ Sekolah Tinggi Agama Kristen Negeri Kupang \\ leryanimanuain@gmail.com \\ Viktor Imanuel Nani \\ Sekolah Tinggi Agam Kristen Negeri Kupang \\ viktornani@gmail.com
}

\begin{abstract}
This Paper is the result of a study of the extent of STAKN Kupang students' understanding of General Church History Periodization. This research uses survey method with samle of 147 people. Data collection techniques using questionnaires and then analyzed in quantitative descriptive. The result showed that the level of understanding of STAKN Kupang students was in the capable category. The Respondents' denomination is in the category of able to very capable. This show that students, lectures and institutions have synergized well; students have a high understanding of the periodization of the history of the general church, lectures teaching with professionals and STAKN Kupang who always maintain and improve the equality of educational institutions. Scientific contributions from this research can be used as a source of study of Christian religious education. Such as hermeneutics, dogmatis, ethics, practica, theology form which can take something to deepen the knowledge and thingking of studet theology.
\end{abstract}

Keywords: level of understanding, the periodization of the general church history

\begin{abstract}
Abstrak
Tulisan ini merupakan hasil kajian tentang sejauh mana tingkat pemahaman mahasiswa STAKN Kupang terhadap periodisasi Sejarah Gereja Umum. Penelitian ini menggunakan metode survei dengan jumlah sample 147 orang. Teknik pengumpulan data menggunakan kuisioner dan kemudian dianalisa secara deskirptif kuantitatif. Hasil penelitian menunjukan bahwa tingkat pemahaman mahasiswa STAKN Kupang berada pada kategori mampu. Denominasi sebaran responden berada pada kategori mampu menuju sangat mampu. Ini menunjukan bahwa mahasiswa, dosen dan lembaga telah bersinergi dengan baik; mahasiswa memiliki pemahaman yang tinggi terhadap Periodisasi Sejarah Gereja Umum, dosen mengajar dengan profesional dan STAKN Kupang yang selalu menjaga dan memperbaiki kualitas lembaga pendidikan. Sumbangan ilmiah dari penelitian ini dapat dijadikan sumber kajian mata kuliah Pendidikan Agama Kristen seperti hermeneutik, dogmatika, etika, teologi praktika yang daripadanya dapat kita ambil sesuatu untuk memperdalam pengetahuan dan pemikiran teologi mahasiswa. Sumbangan ilmiah dari penelitian ini dapat dijadikan sumber kajian mata kuliah Pendidikan Agama Kristen seperti hermeneutik, dogmatika, etika, teologi praktika yangdari padanya dapat kita ambil sesuatu untuk menperdalam pengetahuan dan pemikiran teologi mahasiswa.
\end{abstract}

Kata Kunci: tingkat pemahaman, periodisasi Sejarah Gereja Umum 


\section{Pendahuluan}

Pendidikan Sejarah Gereja Umum merupakan mata kuliah yang mempelajari hakekat keberadaan dan perkembangan gereja sejak awal bedirinya, yaitu pada masa gereja lama, masa pertengahan dan masa gereja baru. Melalui mata kuliah ini, mahasiswa diajarakan untuk memahami berbagai tradisi dan persoalan yang dihadapi oleh gereja dalam masamasa perkembangannya. Pengenalan akan hal ini dipandang penting, sebab perjalanan masa lampau memiliki pengaruh yang kuat terhadap perkembangan gereja modern saat ini. Memahami persoalan masa lalu, memberi kesiapan dan kesanggupan untuk menghadapi persoalan masa kini dalam hubungannya dengan perkembangan gereja.

Kurikulum yang diterapkan oleh Sekolah Tinggi Agama Kristen Negeri (STAKN) Kupang mengakomodir mata kuliah Sejarah Gereja Umum ini dalam dua SKS dan merupakan Mata kuliah prasyarat yang wajib tempuh dan wajib lulus. Hal ini menunjukan bahwa kedudukan mata kuliah Sejarah Gereja Umum dalam kurikulum STAKN Kupang dianggap penting untuk mempersiapkan mahasiswa yang akan menjadi seorang guru agama yang profesional di bidangnya maupun pelaku layanan di gereja kelak. Untuk itu dalam pembelajaran Sejarah Gereja Umum, mahasiswa dituntut untuk memiliki pemahaman konsep Sejarah Gereja Umum terlebih dahulu untuk memahami materi Sejarah Gereja Umum. Akan tetapi, menurut sebagian mahasiswa mata kuliah ini merupakan mata kuliah yang sulit, kondisi tersebut terjadi karena rendahnya tingkat pemahaman mahasiswa terhadap materi yang disampaikan.

Ada banyak faktor yang menyebabkan persoalan ini. Peneliti mengasumsikan beberapa hal yang menyebabkannya, di antaranya: adanya pemahaman bahwa pelajaran sejarah adalah pelajaran tentang masa lalu yang tidak perlu dipelajari karena telah selesai dan tidak memiliki hubungan dengan masa sekarang. Kegagalan menemukan hubungan antara peristiwa sejarah dan masa kini menyebabkan keengganan untuk mempelajarinya.Selanjutnya, mempelajari sejarah, hanya berkaitan dengan kemampuan menghafal berbagai hal yang terkait di dalamnya, seperti waktu, tempat peristiwa, maupun pelaku sejarah, sehingga dalam pembelajaran sejarah mahasiswa mahasiswa lebih fokus kepada bagaimana mereka mendapatkan hasil belajar yang baik dengan menghafal berbagai hal berkaitan dengan sejarah tanpa memiliki pemahamn konsep tentang sejarah gereja itu sendiri.

Sebenarnya untuk mempermudah pemahaman dalam mempelajari sejarah gereja, para ahli telah membuat periodisasi sejarah gereja. Dalam disiplin ilmu Historika, periodisasi merupakan perkara yang sangat penting dan wajib diketahui, sebab sejarah bergerak dalam waktu. Tanpa adanya waktu, sejarah tidak akan pernah terjadi, sedangkan waktu dalam sejarah harus sesuai dengan urutannya, dan urutan sejarah dapat dikenal secara sistematis melalui pembagian periodisasi. Periodisasi dalam sejarah gereja dibagi dalam 3 bagian besar, yaitu: pertama, periode gereja lama (tahun 30 s.d tahun 590); kedua, periode gereja abad pertengahan (tahun 590 s.d. tahun 1492/1517); dan ketiga, periode gereja zaman baru (tahun 1492/1517 s.d. Sekarang). ${ }^{1}$

Searah dengan maksud di atas, penjelasan tentang periodisasi sejarah gereja ini selalu disampaikan oleh dosen pada awal perkuliahan, sebelum masuk pada pokok-pokok bahasan yang akan diajarkan. Periodisasi ini memegang peranan penting untuk mengantar atau membimbing mahasiswa dalam mempelajari Sejarah Gereja Umum. Bangunan pengetahuan tentang sejarah gereja secara umum kelak, dipengaruhi oleh sejauh mana mahasiswa memahami periodisasi sejarah gereja.

Tetapi pada titik ini pun tingkat pemahaman mahasiswa masih dipertanyakan. Inilah yang menjadi dasar penelitian ini dilakukan yaitu untuk mengukur tingkat pemahaman

\footnotetext{
${ }^{1}$ C. De Jong, Pembimbing ke dalam Sejarah Gereja, (Jakarta: BPK Gunung Mulia, 2015$), 49$.
} 
mahasiswa tentang periodisasi Sejarah Gereja. Manfaat dari penelitian ini adalah untuk memperoleh pemahaman yang menyeluruh berkaitan dengan pemahaman mahasiswa STAKN Kupang terhadap periodisasi Sejarah Gereja Umum, demi menemukan strategi untuk mengatasi persoalan tersebut.

\section{Metode Penelitian}

Penelitian ini bertujuan untuk mengetahui seberapa besar tingkat pemahaman mahasiswa STAKN Kupang Jurusan Pendidikan Agama Kristen terhadap periodisasi Sejarah Gereja Umum. Jenis penelitian ini adalah kuantitatif dengan metode survei yaitu penelitian yang digunakan pada populasi besar maupun kecil, tetapi data yang dipelajari adalah data dari sampel yang diambil dari populasi tersebut, sehingga ditemukan kejadiankejadian relatif, distribusi dan pengaruh dan hubungan-hubungan antar variabel. ${ }^{2}$

Sampel dalam penelitian ini adalah mahasiswa semester III Sekolah Tinggi Agama Kristen Negeri Kupang. Penentuan sampel diambil dari populasi yang berjumlah sekitar 320 orang. Dari populasi tersebut kemudian peneliti menentukan jumlah sampel dengan menggunakan Nomogram Herry King sehingga jumlah sampel dengan taraf kesalahan 10\% adalah sebanyak 147 orang. ${ }^{3}$ Penggunaan rumus Nomongram Herry King dengan pertimbangan bahwa rumus ini representatif (mewakili), sederhana untuk mendapatkan hasil yang pasti dari keseluruhan mahasiswa yang diteliti serta lebih akurat.

Pengumpulan data dilakukan dengan menyebarkan kuesioner kepada 147 respoden. Penentuan responden ini dilakukan dengan menetapkan kriteria yaitu mahasiswa yang sedang menempuh mata kuliah Sejarah Gereja Umum. Instrumen penelitian yang digunakan dalam mengukur nilai variabel yang diteliti menggunakan skala pengukuran likert dengan jawaban sangat setuju (5), setuju (4), ragu-ragu (3), tidak setuju (2), sangat tidak setuju (1).

Dalam melakukan analisis data peneliti tidak merumuskan hipotesis. Oleh Karena itu analisis data dilakukan hanya untuk menentukan persentase dan nilai interval yang dapat dilihat pada tabel berikut:

Tabel 1.1

Nilai Persepsi, Interval Konversi dan tingkat Pemahaman Mahasiswa

\begin{tabular}{|c|c|c|}
\hline Nilai Persepsi & $\begin{array}{c}\text { Nilai Interval Pemahaman } \\
\text { Mahasiswa }\end{array}$ & Tingkat Pemahaman \\
\hline 1 & $35-62$ & Tidak Mampu \\
\hline 2 & $69-30$ & Kurang Mampu \\
\hline 3 & $91-118$ & Cukup Mampu \\
\hline 4 & $119-146$ & Mampu \\
\hline 5 & $47-175$ & Sangat Mampu \\
\hline
\end{tabular}

\section{Pemahaman Mahasiswa STAKN Kupang Terhadap Periodisasi Sejarah Gereja Umum}

Pemahaman dalam pembelajaran merupakan tingkat kemampuan yang mengharapkan seseorang mampu memahami arti atau konsep, situasi atau fakta yang diketahuinya, sehingga seseorang tidak hanya menghafal secara verbalitas, tetapi memahami konsep dari masalah atau fakta yang ditanyakan. ${ }^{4}$ Menurut Anderson dan

${ }^{2}$ Fred N. dan Howard B. Lee, Foundations of Behavioral Research, (Forth Worth: Harcout College Publisher, 2000), 599.

3Sugiono, Metode Penelitian Kombinasi, (Bandung:ALFABETA, 2016), 131.

${ }^{4}$ Ngalim Purwanto, Prinsip-prinsip dan Teknik Evaluasi Pengajaran, (Bandung: PT Remaja Rosdakarya, 2013), 44. 
Kratwohwohl dalam Revisi toksonomi Bloom seseorang dikatakan memahami bila mereka dapat menghubungkan pengetahuan baru dengan pengetahuan lama. Lebih tepatnya pengetahuan bari dipadukan dengan skema-skema dan kerangka-kerangka kognitif yang telah ada. Proses-proses kognitif dalam kategori memahami meliputi menafsirkan, mengklasifikasi, menyimpulkan, membandingkan dan menjelaskan. ${ }^{5}$

Periodisasi dalam sejarah gereja di bagi dalam tiga bagian besar, yaitu: (1) gereja kuno (30-590). Masa ini dimulai dengan berdirinya gereja hingga runtuhnya kekaisaran Roma Barat dan naiknya Gregorius Agung sebagai Paus yang pertama. Gereja lahir dan berkembang dalam wilayah kekaisaran Roma hingga hancurnya kekaisaran Roma pada abad ke-6.; (2) gereja abad pertengahan (590-1492/1517); dan (3) gereja pada zaman baru (1492-1517-kini). ${ }^{6}$

Berbicara tentang pemahaman terhadap periodisasi Sejarah Gereja Umum, penelitian ini bertujuan untuk mengetahui berapa besar tingkat pemahaman mahasiswa STAKN Kupang tehadap periodisasi Sejarah Gereja Umum. Berdasarkan deskripsi hasil penelitian diperoleh data bahwa tingkat pemahaman mahasiswa STAKN Kupang terhadap periodisasi Sejarah Gereja Umum adalah $77,5 \%$. Hal ini menunjukan bahwa sebagian besar mahasiswa STAKN Kupang telah memahami periodisasi Sejarah Gereja Umum. Hal ini ditunjukan melalui hasil perhitungan statistika kemampuan pemahaman mahasiswa yang dapat diperinci dalam setiap indikator sebagai berikut:

1. Menafsirkan

Menafsirkan terjadi ketika mahasiswa mampu mengubah informasi yang diterima dalam bentuk bentuk lain. Menafsirkan berupa pengubahan kata-kata jadi kata-kata lain, gambar dari kata-kata, kata-kata jadi gambar, angka jadi kata-kata, kata-kata jadi angka. ${ }^{7}$ Kemampuan mahasiwa dalam menafsrikan didasarkan pada kemampuan mahasiswa dalam memparafrasakan, menerjemahkan, menggambarkan dan mengklarifikasi Periodisasi Sejarah Gereja Umum.

Hasil penelitian berkaitan dengan kemampuan menafsirkan menunjukan bahwa secara keseluruhan rata-rata kemampuan mahasiswa dalam menafsirkan periodisasi Sejarah Gereja Umum berpusat pada kategori mampu sebanyak 84 orang atau sebesar $57,1 \%$ dan sangat mampu sebanyak 36 orang atau sebesar $24,5 \%$, sedangkan respon mahasiswa pada kategori kurang mampu sebanyak 26 orang atau sebesar $17,7 \%$, dan respon mahasiswa pada kategori tidak mampu sebanyak 1 orang atau sebesar 0,68\%. Angkat tersebut menunjukan bahwa kemampuan menafsirkan mahasiswa pada indikator ini berada pada kategori mampu untuk menafsirkan periodisasi Sejarah Gereja Umum. Kemampuan menafsirkan ini terlihat pada kemampuan mahasiswa dalam memparafrasakan makna, syarat, pembagian dan ciri dari periodisasi Sejarah Gereja Umum. Kemampuan mahasiswa pada kategori tidak mampu berkaitan dengan kemampuan mahasiswa dalam memparafrasakan kembali tentang makna periodisasi Sejarah Gereja Umum dan syarat dari periodisasi Sejarah Gereja Umum.

\section{Mengklasifikasi}

Proses kognitif klasifikasi terjadi ketika mahasiswa mengetahui bahwa sesuatu (misalnya suatu contoh) termasuk dalam kategori tertentu (misalnya konsep atau prinsip). Klasifikasi melibatkan ciri-ciri atau pola-pola yang sesuai contoh atau prinsip tersebut ${ }^{8}$

${ }^{5}$ Lorin W. Anderson dan David R. Kratwohl, Lorin W. Anderson dan David R. Kratwohl, Kerangka Landasan Untuk Pembelajaran, Pengajaran. Asesmen Revisi Toksonomi Pendidikan Bloom, (Yokyakarta: Pustaka Pelajar, 2014), 106.

${ }^{6}$ C. De Jonge, Pembimping ..., 49.

${ }^{7}$ Lorin W. Anderson dan David R. Kratwohl, Lorin W. Anderson dan David R. Kratwohl, Kerangka Landasan Untuk Pembelajaran..., 106.

8 Ibid., 109. 
mahasiwa dikatakan mampu mengklasifikasi jika ia dapat menentukan ciri-ciri dan pola yang sesuai dengan contoh dan konsep atau prinsip tersebut.

Rata-rata kemampuan mahasiswa dalam mengklasifikasi periodisasi Sejarah Gereja Umum berada pada kategori mampu yaitu sebanyak 72 orang atau sebesar $49 \%$ kemudian diikuti oleh kategori sangat mampu yaitu sebanyak 62 orang atau sebesar $42,2 \%$, Sedangkan kategori cukup mampu sebanyak 13 orang atau sebesar 8,84\%, dan kategori tidak mampu tidak mendapat tanggapan responden. Kemampuan mahasiswa dalam mengklasifikasi ini terlihat pada kemampuan mahasiswa dalam mengelompokan dasar organisasi dan mengkategorikan berbagai peristiwa sesuai dengan periodisasi Sejarah Gerja Umum. Ketidakmampuan mahasiswa dalam mengklasifikasi berbagai peristiwa dan tokoh pada periodisasi Sejarah gereja masa kini atau saman baru.

3. Menyimpulkan

Proses kognitif menyimpulkan menyertakan proses menemukan pola dan sejumlah contoh. Menyimpulkan terjadi ketika mahasiswa dapat mengabstrasikan sebuah konsep atau prinsip yang menerangkan contoh-contoh tersebut dengan menarik hubungan di antara ciriciri tersebut. ${ }^{9}$ Misalnya seorang mahasiswa dikatakan mampu menyimpulkan mengapa sebuah peristiwa terjadi periodisasi Sejarah Gereja Umum tertentu.

Jumlah responden pada kemampuan menyimpulkan berada pada kategori mampu sebanyak 90 orang atau sebesar $61,2 \%$ dan kemampuan mahasiwa pada kategori sangat mampu sebanyak 47 orang atau sebesar $28,6 \%$. Sedangkan respon mahasiswa pada kategori cukup mampu sebanyak 14 orang atau sebesar 9,52\%, kurang mampu sebanyak 1 orang atau sebesar $0,68 \%$ dan tidak mampu berada pada angka 0 atau $0,00 \%$. Artinya bahwa tidak terdapat mahasiswa yang tidak memiliki kemampuan menyimpulkan periodisasi Sejarah Gereja Umum. Kemampuan mahasiswa dalam menyimpulkan terlihat ketika mahasiswa dapat menyimpulkan makna periodisasi sejarah gereja dan syarat-syarat dari periodisasi Sejarah Gereja Umum.

4. Membandingan

Proses kognitif membandingkan ini melibatkan proses mendeteksi persamaan atau membandingkan ini, mahasiswa telah memiliki kemampuan menentukan hubungan antara dua ide, dua atau lebih objek, peristiwa, ide, masalah, atau situasi, seperti menentukan bagaimana suatu peristiwa terkenal menyerupai peristiwa yang kurang terkenal. Nama lain dari membandingkan adalah mengontraskan, memetakan dan mencocokan.10

Tingkat kemampuan membandingkan telah berada pada kategori mampu. Secara lengkap dapat dipaparkan bahwa sebaran responden berpusat pada kategori mampu sebanyak 79 orang atau sebesar $53,7 \%$, sangat mampu sebanyak 47 orang atau sebesar $32 \%$, sedangkan pada sisi berlawanan yaitu cukup mampu dan kurang mampu masing-masing sebanyak 19 orang atau sebesar $29 \%$ dan 2 orang atau sebesar 1,36\%. Kategori tidak mampu tidak mendapatkan respon sama sekali. Kemampuan mahasiswa dalam membandingkan terlihat pada kemapuan mahasiswa dalam memetakan sejarah perkembangan gereja pada masa kuno pada umumnya berada di wilayah kekaisaran Roma, sedangkan gereja abad pertengahan agama Kristen mulai tersebar ke batas-batas utara dan Timur Laut benua Eropa, gereja masa kuno memandang Alkitab sebagai satu-satunya sumber kebenaran, sedangkan pada abad pertengahan gereja memandang tradisi dan Alkitab sejajar sebagai sumber kebenaran. Sedangkan ketidakmampuan mahasiswa dalam membadingkan rata-rata berada pada item pertanyaan yang sama yaitu berada pada pernyataan gereja pada abad pertengahan yang tunduk dan patuh pada kebijakan Paus, sedangkan gereja pada zaman baru mulai munculnya usaha untuk mengkritik kebijakan Paus.

${ }^{9}$ Ibid., 111.

${ }^{10}$ Ibid., 113. 


\section{Menjelaskan}

Proses kognitif menjelaskan berlangsung ketika mahasiswa dapat membuat dan menggunakan model sebab-akibat dalam sebuah sistem. ${ }^{11}$ Misalnya mahasiswa dapat menjelaskan tentang sebab-sebab terjadinya peristiswa-peristiwa penting dalam setiap periode Sejarah Gereja Umum.

Hasil penelitian berkaitan dengan kemampuan menjelaskan berada pada kategori mampu yaitu sebanyak 72 orang atau sebesar $49 \%$ dan diikuti oleh kategori sangat mampu sebanyak 39 orang atau sebesar $26,5 \%$, cukup mampu sebanyak 33 orang atau sebesar $22,4 \%$. Jumlah ini lebih tinggi dibandingkan dengan responden yang menanggapi kurang mampu sebanyak 3 orang atau sebesar 2,04\%, dan frekuensi responden pada tingkat tidak mampu hanya berada pada angka 0 atau $0,00 \%$. Artinya tidak ada responden yang memberikan penilaian tidak mampu dalam menjelaskan periodisasi Sejarah Gereja Umum.

Berdasarkan pembahasan di atas, diperoleh data bahwa rata-rata tingkat pemahaman mahasiwa STAKN Kupang terhadap Peridisasi Sejarah Gereja Umum berada pada kategori mampu. Secara lengkap dapat dipaparkan bahwa sebaran responden berpusat pada kategori mampu sebanyak 99 orang atau sebesar $67,35 \%$, diikuti sangat mampu sebanyak 34 orang atau sebesar $23,13 \%$ dan cukup mampu sebanyak 14 orang atau sebesar 9,52\%. Kategori tidak mampu tidak mendapatkan respon sama sekali.

Dari paparan data tersebut menunjukan bahwa rata-rata tingkat pemahaman mahasiswa terhadap periodisasi Sejarah Gereja berada pada kategori mampu. Nilai interval tingkat pemahaman mencapai angka 135,55.12 Artinya mahasiswa STAKN Kupang telah memahami periodisasi Sejarah Gereja Umum. Kemampuan ini terlihat melalui respon yang tinggi pada setiap indikator pemahaman yaitu kemampuan menafsirkan, mengklasifikasi, menyimpulkan, membandingkan dan menjelaskan.

\section{Kesimpulan}

Dari pembahasan yang telah dilakukan, peneliti menemukan bahwa mahasiswa STAKN Kupang memiliki pemahaman yang sangat tinggi terhadap periodisasi Sejarah Gereja Umum, di mana sebaran responden berpusat pada kategori mampu menuju sangat mampu yang terperinci pada setiap indikator pemahaman, yaitu menafsirkan, meklasifikasi, menyimpulkan, membandingkan dan menjelaskan. Hal ini memberikan makna sangat kuat bahwa mata kuliah Sejarah Gereja Umum sangat diminati oleh mahasiswa STAKN Kupang. Selain itu, kemampuan profesional dosen sebagai pengajar mata kuliah Sejarah Gereja Umum dan juga lembaga yang selalu menjaga dan memperbaiki kualitas lembaga pendidikan turut memberi sumbangsih terhadap keberhasilan mahasiswa.

\section{Rekomendasi Untuk Penelitian Lanjutan}

Peningkatan pemahaman mahasiswa STAKN Kupang terhadap periodisasi Sejarah Gereja sangat diperlukan, karena mata Kuliah Sejarah Gereja merupakan sumber yang kaya untuk mata kuliah Pendidikan Agama Kristen seperti hermeneutik, dogmatika, etika, teologi praktika yang daripadanya dapat kita ambil sesuatu untuk memperdalam pengetahuan dan pemikiran teologi mahasiswa. Hasil penelitian ini diharapkan bisa menjadi acuan bagi peneliti selanjutnya untuk lebih mengembangkan penelitian ini dengan menerapkan penggunaan metode atau media pembelajaran.

11 Ibid., 105-115

${ }^{12}$ Lihat kembali tabel 1.1. Nilai Persepsi, Interval Konversi dan Tingkat Pemahaman Mahasiswa 


\section{Rujukan}

Anderson, Lorin W. \& Kratwohl, David R. Kerangka Landasan Untuk Pembelajaran, Pengajaran. Asesmen Revisi Toksonomi Pendidikan Bloom, Yokyakarta: Pustaka Pelajar, 2014.

Azwar, Saifuddin. Reliabilitas dan Validitas.Yogyakarta: Pustaka Pelajar, 2003.

Berkhof, H. \& Enklaar, I.H. Sejarah Gereja. Jakarta: BPK Gunung Mulia, 2001.

Culver, Jonathan E. Sejarah Gereja Umum. Bandung: Biji Sesawi, 2013.

De Jong, C. Pembimbing ke dalam Sejarah Gereja.Jakarta: BPK Gunung Mulia, 2015.

Departemen Pendidikan dan Kebudayaan. Kamus Besar Bahasa Indonesia, Jakarta: Balai Pustaka, 2003.

Djaali. Psikologi Pendidikan. Jakarta: Bumi Aksara, 2011.

Hadi, Sutrisno. Metodologi Research 2.Yogyakarta: Fakultas Psikologi Universitas Gajah Mada, 2002.

Kuhl, Dietrich. Gereja Mula-mula Sejarah Gereja Jilid I. Batu: YPPII, 1998.

N. Fred \& B. Lee, Howard. Foundations of Behavioral Research.Forth Worth: Harcout College Publisher, 2000.

Nasution. Teknologi Pendidikan. Jakarta: Bumi Aksara, 2012.

Ngalim Purwanto. Prinsip-prinsip dan Teknik Evaluasi Pengajaran. Bandung: PT Remaja Rosdakarya, 2013.

Moeljadi, David dkk. (Pengembang), “KBBI offline Versi 0.2.1 Beta (21)”, Badan Pengembangan dan Pembinaan Bahasa, Kementerian Pendidikan dan Kebudayaan Republik Indonesia, 2016.

S, Jonar. Sejarah Gereja Umum. Yogyakarta: Andi Offset, 2014.

Sudaryono. Dasar-dasar Evaluasi Pembelajaran. Yokyakarta: Graha Ilmu, 2012.

Sudjana, Nana. Penilaian Hasil Proses Belajar Mengajar. Bandung: PT Remaja Rosmadakarya, 2014.

Sugiyono. Statistika untuk Penelitian.Bandung: Alfabeta, 1999. Metode Penelitian Kombinasi (Mixed Methods). Jakarta: Alfabeta, 2016.

van Den End, Th. Harta Dalam Bejana. Jakarta: BPK Gunung Mulia, 2000. 